crease in the electromotive force of the cell, in fact calculation gives the following figures:

For pure carbon dioxide. Electromotive Forc 0.997 volts

For 99 per cent $\mathrm{CO}, 1$ per cent $\mathrm{CO}_{2} \ldots 1.129$ The values found should lie between these two extremes, as, in fact, they do.

The problem of constructing a reversible carbon cell is therefore solved.

An important circumstance, from the technical point of view, is the fact that the cell is capable of furnishing a very considerable current without losing appreciably in its electromotive force, and furthermore, the internal resistance of the cell is relatively small. We found no observable polarization with a current density of 100 amperes per square meter.

The prospects of a commercial exploitation of the carbon cell are therefore good. The principal question that now faces us, is whether the shaped coke electrodes can be made sufficiently cheaply. If the ton of coke costs $\$ 5$ (German prices), and the carbon is burnt to $\mathrm{CO}$ in the cell, furnishing an electromotive force of 1 volt, the kilowatt hour costs 1.25 cents. But the electrodes used at the present day in carbide and electrochemical steel furnaces cost $\$ 45$ to $\$ 50$ per ton (German prices). With these it would not be possible to work economically.
The carbon monoxide we cannot look upon as a byproduct, for at least a part of it would be consumed in heating up the cells.

The price of silver might at first be thought prohibitive. But it is not impossible that by economical use of the metal the investment of a large amount of capital might be avoided.

As regards the recovery of waste heat and the durability of the vessels employed, modern glass industry is quite able to take care of this. Lastly, a number of minor difficulties of construction remain to be disposed of. But so far as the author can see, they are no more serious than those commonly met in developing a new process.

\title{
The Largest Reinforced Concrete Bridge in America
}

\author{
A Viaduct with a Clear Span of Over 300 Feet
}

\author{
By Frank C. Perkins
}

The accompanying illustration shows the construction of the Larimer Avenue bridge at Pittsburgh, $\mathrm{Pa}$, which is said to be the largest reinforeed conerete arch bridge in America. It has a clear span of 300 feet inches.

This reinforced concrete bridge replaced a combina-

to center. They have a varying depth from 6 feet inches at the crown to 11 feet at the springing line. They are braced together by struts spaced 19 feet inches center to center. The rise from the springin line to the summit of the arch at the center line is 67 feet $1 / 2$ inch. The approaches on either side of the mai

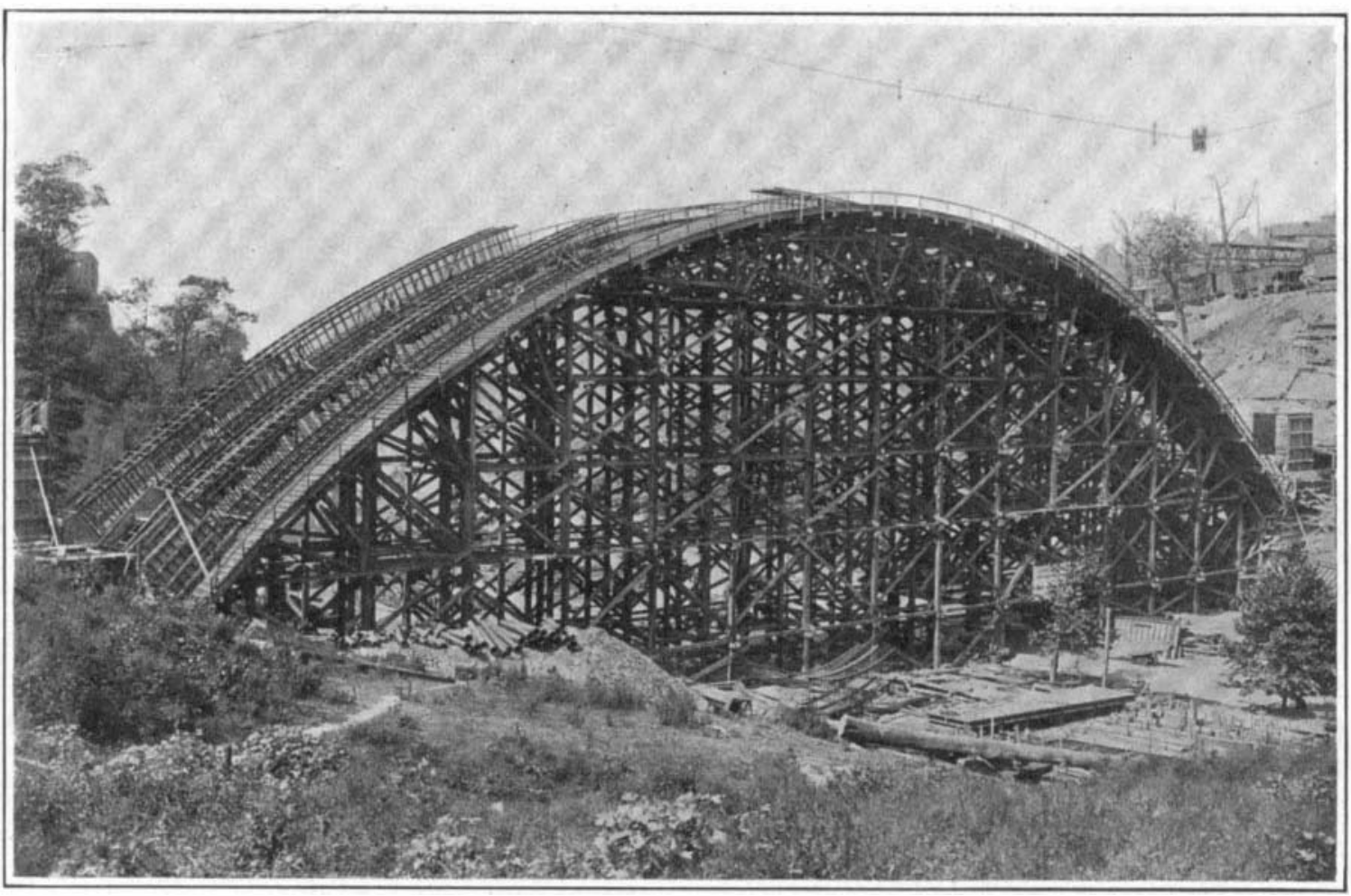

Falsework for the Main Arch Rib.

tion of wood and iron viaduct that was built in 1891 and 1892 , consisting of 60 -foot spans on wooden towers. The length over all of the bridge is 670 feet. It is 50 feet in width, with two sidewalks each 10 feet wide, and is $\mathbf{1 1 0}$ feet above the ground. It was designed and constructed under the supervision of J. G. Armstrong, director of the Bureau of Construction of the Department of Public Works of Pittsburgh.

The main arch consists of two arch ribs, and a reinforced concrete beam, and slab floor, supported by panel piers from the main arch rib. The arches are approximately parabolic form, and consist of two parallel ribs, having a uniform width of $\&$ feet spaced 30 feet cente span consist of semi-circular arches spanning 30 feet center to center and 25 feet in the clear, and a reinforced concrete beam and slab floor.

The falsework for the main arch ribs shown in one of our illustrations consisted of 251,815 board feet long leaf yellow pine. All forms were built of $\mathrm{T} / 8$ inch matched pine, and as far as possible were made up into panels. The studding was 2 by 6 -inch material and braced by horizontal walings of 4 by 6 pine, spaced feet center to center.

The concreting of the main arch rib was placed in individual sections. The lower section adjoining the main piers was poured monolithic with the lower base of the main piers. The two sections at the crown of each rib were poured first, then followed the lowest sections, and so on, working toward the top. The forms for the beam and fioor system over the main arch, shown in our illustrations, were completed from end to end before concrete was placed. The concrete was then placed in sections 19 feet 6 inches long, starting in the center of the span and alternately working from the center toward the end on both sides of the arch.

The reinforcement of the main arch rib consists of large size steel angles, used extensively, each rib having a longitudinal framework of eight angles, 6 inches by 4 inches by $3 / 4$ inch, forming a deep lattice girder. The structure comprises a central I section girder of four angles, and at each corner of the rib section a single additional angle, the whole well connected by transverse flat bars.

The reinforcement consisted of Mueser diamond bars with the exception of the steel angles previously mentioned. Crushed limestone was used in the concrete for all parts of the bridge above the ground level and gravel in those sections below the ground. Universal Portland cement and Allegheny River sand were used throughout the whole bridge.

The parement of the roadway of this bridge is of special interest. The roadway of the bridge is covered with a gravel fill on the concrete slab, 8 inches deep at the center and shading off to nothing at the curbs. A 6-inch layer of $1: 3: 6$ concrete was placed over this, then a 1-inch binder and a 2-inch sheet of asphalt, bringing the final surface of the middle of the roadway 1-inch below the curb grade.

In order to provide for the expansion and contraction of the roadway, joints were located at the abutments, over the main piers and over the third spandrel column from the main piers. The Larimer Avenue arch is noteworthy for the very successful surface finish obtained upon it. The main surfaces everywhere were bush-hammered, giving the surface an excellent texture and very uniform color tone.

The construction plant is also of great interest and the principal feature of the plant installation was a cableway, with towers 60 feet high and four spans of 750 feet. The towers were placed on tracks and and an 814 by 1 a engine. The total yardage of the bridge amounted to 9,471 cubic yards of concrete, 71,178 square feet of bush-hammering, $\$ 92,540$ pounds of reinforcement steel, and 2,233 square yards of pavement

\section{The Changing Cost of Living*}

\section{Comparative Measurements at Home and Abroad}

By Prof. J. Pease Norton

THE changing cost of living is a fundamental cause of many reactions in the complexes of social phenomena. In fact, it is probable that an economic interpretation of many important historical movements may be developed from future htudy of such events as effects of this probable fundamental cause of radical movements in human societies, such as extensive revolutions and even international wars.

Political economists, at any rate, should hold always before them the idea that mankind is subject first to the primary economic problems of self-maintenance.

*Address of the vice-president and chairman of section I, American Association for the Advancement of Science, Cleveland, January 3rd, 1913. Published in Science.
The changing cost of living is another phrase to denote in a civilized society this factor of relative self-maintenance which is so important in the study of the more primitive societies. Thus, on the side of the consumption of commodities, we may measure the changing cost of the primary necessities in ter ms of the prices of the markets.

With the development of markets and with the establishing of standard grades for leading commodities, it becomes possible to fix rather definitely comparative prices of all of the more important commodities. A a result, we may compare with a considerable degree of accuracy the fluctuations in the changing cost of living over a series of: successive years. Of couers, the greater problem of constructing an index number of relative welfare which shall combine in some rational way the general concepts of the cost of living and of we the gene of many interesting conclusions, but this problem at the present time is extremely difficult.

In this paper, which is divided into three parts, I shall present, first, the results of original computations of two series of index numbers for American prices. Hitherto, the purpose of index numbers has been chiefly to measure the changing cost of living in order to compare the relative conditions of suceessive years for the ame country.

In the second part of this paper, I have endeavored 


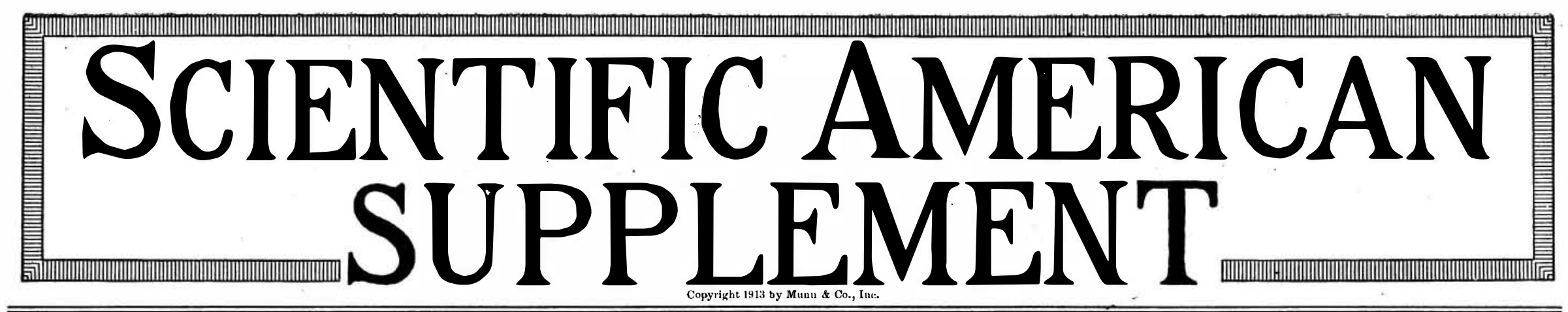

VOLUME LXXV ]
NUMBER 1952 ]

NEW YORK MAY 31, 1913

$\left[{ }^{10}\right.$ GENTST A A COPY

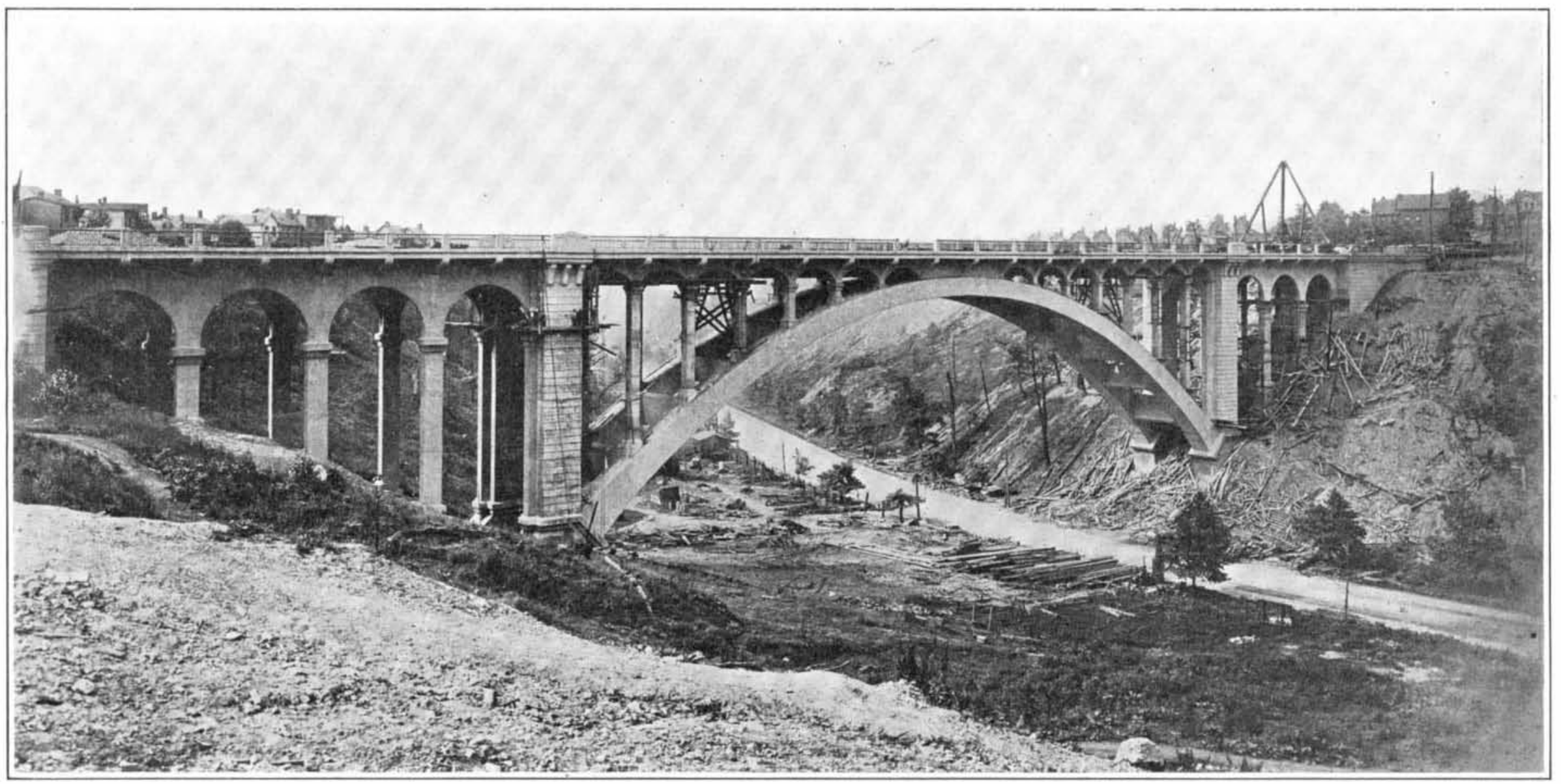

View of the Completed Lorimer Avenue Bridge, Pittsburgh, Pa., Looking North.

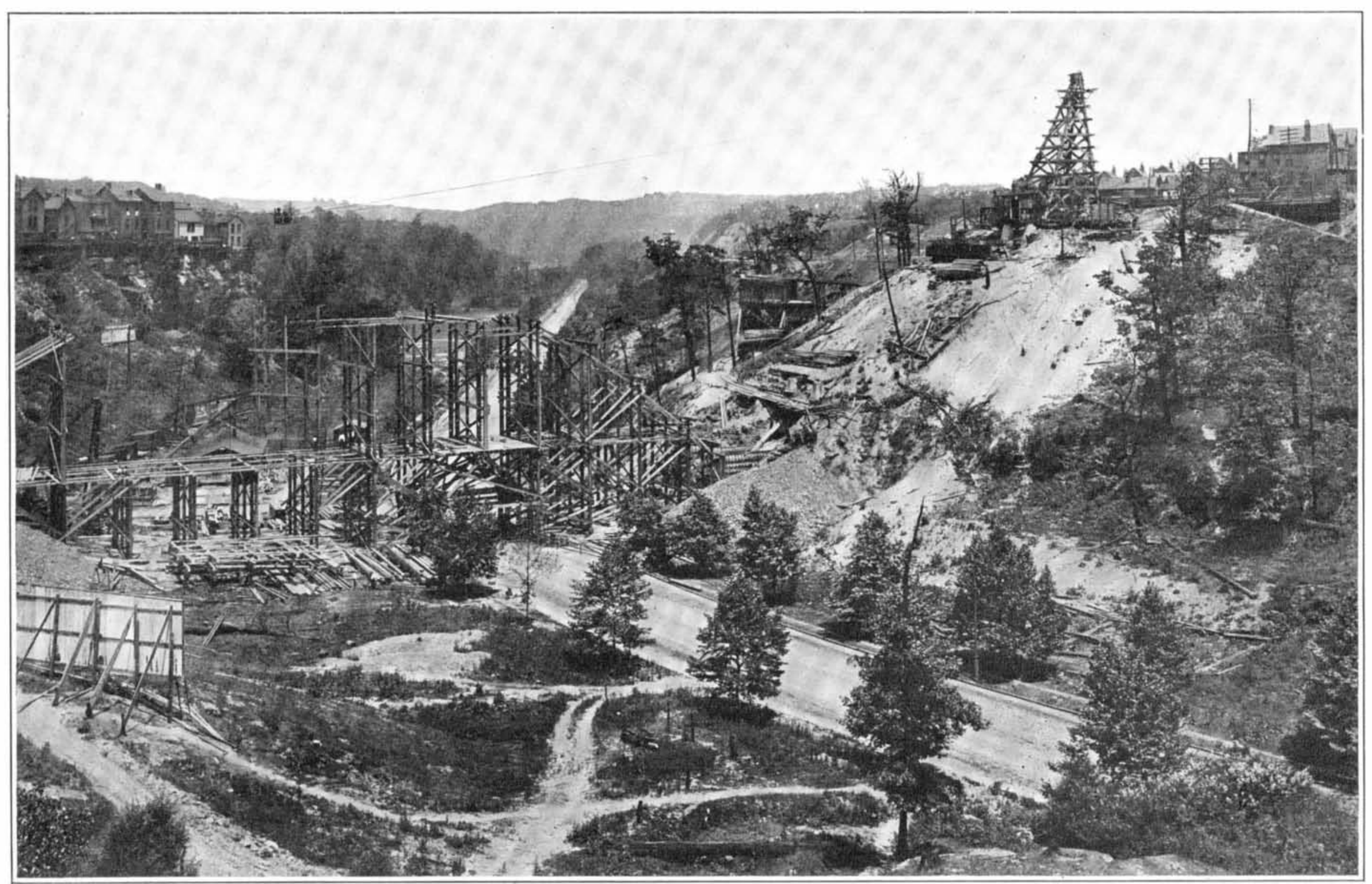

View Showing the Valley Over Which the Bridge is Carried.

THE LARGEST RE-ENFORCED CONCRETE BRIDGE IN AMERICA.-[See page 348.] 